DOI 10.18551/rjoas.2020-08.06

\title{
SOCIO-ECONOMIC FACTORS INFLUENCING PERCEPTIONS AND ADAPTABILITY OF RURAL RICE FARMERS TO CLIMATE CHANGE, ABUJA, NIGERIA: APPLICATIONS OF HECKMAN TWO-STAGE MODEL
}

\author{
Alabi Olugbenga Omotayo \\ Department of Agricultural Economics, University of Abuja, Gwagwalada-Abuja, Nigeria \\ Oladele Ayoola Olugbenga \\ Department of Agricultural Extension and Management, Federal College of Forestry \\ Mechanization, Forestry Research Institute of Nigeria (FRIN), Kaduna, Nigeria \\ Oladele Nath Olarotimi \\ Trial Afforestation Research Station, Forestry Research Institute of Nigeria (FRIN), \\ Kaduna, Nigeria
}

*E-mail: omotayoalabi@yahoo.com

\begin{abstract}
This study analyzed socio-economic factors influencing perceptions and adaptability of rural rice farmers to climate change, Abuja, Nigeria: applications of Heckman two - stage model. Specifically, the study was designed to achieve the following objectives: describe the socioeconomic profiles or characteristics of rural rice farmers, determine the perceptions of rural rice farmers to climate change, determine the adaptation or coping strategies of rural rice farmers to climate change, evaluate socio-economic factors influencing or affecting perceptions and adaptability of rural rice farmers to climate change, and determine the problems or constraints facing rural rice farmers adaptability to climate change. Primary data were employed with the use of well-structured, well-designed questionnaire. Multi-stage sampling was adopted and used. Total sample sizes of 100 rice farmers were employed. The statistical and econometric tools employed were: descriptive statistics, four-point Likert scale, perception use index, problem confrontation index, adaptation or coping strategies use index, Heckman two-stage model, and t-test analysis. The results show that $73 \%$ of rural rice farmers were less than 50years of age. About $96 \%$ of rural rice farmers had formal education. The average rural rice farms were 2.28 hectares. Rural rice farmers perceived and ranked the events of climate change they include: reduced yields $\left(1^{\mathrm{st}}\right)$, changes in time and date of planting $\left(2^{\text {nd }}\right)$, increased rainfall $\left(3^{\text {rd }}\right)$, and flood occurrence $\left(4^{\text {th }}\right)$ based on perception use index. The adaptive measures employed by rural rice farmers to reduce the impact of climate change was ranked and they include: practicing intercropping $\left(1^{\text {st }}\right)$, changing time and date of planting $\left(2^{\text {nd }}\right)$, crop diversification $\left(3^{\text {rd }}\right)$, and use of improved varieties $\left(4^{\text {th }}\right)$ based on adaptive use index. Heckman two-stage results show that factors statistically and significantly influencing perceived events of climate change include: age $(\mathrm{P}<0.01)$, educational status $(\mathrm{P}<0.01)$, access to information on climate change $(\mathrm{P}<0.01)$, farm experience $(P<0.01)$, farm size $(P<0.05)$, and extension services $(P<0.01)$. Factors statistically and significantly influencing adaptive measures employed by rural rice farmers to reduce the impacts of climate change include: age $(P<0.05)$, gender $(P<0.05)$, household size $(P<0.05)$, educational status $(P<0.01)$, access to credit facilities $(P<0.01)$, farm experience $(P<0.05)$, farm size $(P<0.05)$, access to adaptive measures $(P<0.01)$, extension services $(\mathrm{P}<0.01)$, and access to input and output markets $(\mathrm{P}<0.01)$. The Wald Chi Square value of 78.61 was significant at $(\mathrm{P}<0.01)$. The coefficients of multiple determinations $\left(\mathrm{R}^{2}\right)$ was 0.7943 . The $\mathrm{F}$-value of 363.92 was significant at $(\mathrm{P}<0.01)$. This explains the joint effects of the exogenous variables included in the model in explaining variations in the choice of adaptive measures employed by rural farmers in reducing the impacts of climate change. Problem confrontation index revealed that bad road infrastructures ranked $1^{\text {st }}$, lack of information on climate change ranked $2^{\text {nd }}$, lack of access to
\end{abstract}


input and output markets ranked $3^{\text {rd }}$, and lack of irrigation facilities ranked $4^{\text {th }}$.Principal component analysis shows that lack of information on climate change, bad road infrastructures, lack of irrigation facilities, and lack of access to markets were the constraints facing rural rice farmers that have Eigen values greater than one, and the components retained explained $78.69 \%$ variations of all the components included in the model. The study recommends that policy measures should be put in place to inform rural farmers through print media, schools, radio, television, internet, social media, and farmers to farmers contact on climate change. Extension officers should be employed to bring research findings, improved varieties, new innovations and information on climate change to rural rice farmers.

\section{KEY WORDS}

Heckman two-stage model, socio-economic characteristics, climate change, rice, farmers, Nigeria.

Rice (Oryza sativa) is a staple, stable food cereal crop that is important for Nigerians and the world at large (Agbodo, Udouso, and Tiku, 2013). In most countries, the rate of consumption of rice is increasing, and this makes those countries import dependent. The annual consumption growth rate of rice in Nigeria is $4.4 \%$ (IFDC). In Nigeria close to 5.4 million metric tonnes of rice were consumed annually. Nigeria can only produce 2.3 metric tonnes of rice per annum, the balance of about 3.1 metric tonnes will be imported (Abah, Abu, and Ater, 2015). Rice can supply $27 \%$ dietary energy and $20 \%$ dietary intake of protein (Edoka, Adejoh, and Ibrahim, 2008).In Nigeria, rice is used in our homes for preparation of local dishes, for ceremonies, and festivals (Ekeleme, Karama, Omoigui, Tegbaru, Mshelia, and Onyibe, 2008). Evidence from science shows that earth's climate is changing rapidly due to increasing greenhouse gas emissions (Stern, 2006). Extreme climate change events include: higher temperatures, drought, flood, warming, reduced rainfall, and increased rainfall. Climate change can reduce yields of crop and this can result to food insecurity in sub-Saharan Africa or developing nations like Nigeria. Adaptation to climate change can reduce the vulnerability and risks faced by farmers, Climate change adaptability can be specific to locations. Impact of climate change can be managed by adaptation. Adaptation to climate change is very important for developing nations like Nigeria, this will ensure livelihoods for resource poor farmers. Smallscale farmers have been affected by climate change due to changes in the amount and distributions of rainfall which have resulted into low precipitations and drought. The effects of climate change are tackled with adaptation, while the cause of climate change is tackled with mitigation (MERET, 2009).In developing countries now, what is critical is adaptation. Adaptation to climate change can be explained in two -stage process. Firstly, is the perceptions that climate is changing, secondly, is the farmers respond to climate change through method of adaptation. Climate changes have the potentials to affect severely countries that depend highly on farming. Farmers will require varieties of adaptation strategies to reduce the effects of climate change. Adaptation strategies to climate change include: planting of heat and drought resistance varieties, adopting soil and water conservation methods, use of fertilizers, use of irrigation facilities or equipment's, tree planting, planting improved varieties, changing timing and date of planting, crop diversification, integrating crop with livestock, diversifications to activities that are nonfarm in nature, information on climate and weather to farmers, crop insurance, farm practices, management of resources and innovative ideas, use of sheltering and shading techniques. Farmers have high likelihood or probability to adapt to climate change if they have access to extension services, have access to credit facilities, and have land input (Evans et al, 2011).Climate changes have varying degrees of negative effects on food production, in various types of ecosystems. The extent or degree of impact depends mostly on the level of adaptations (Marambe et al, 2012b).

In sub-Saharan Africa, climate changes have affected smallscale farmers who depend heavily on rainfed agriculture. The climate changes have raised or increase the average temperature, distributions and amount of rainfall have been altered. Farmers need to 
understand the effects of climate change, as limiting the effects of climate change due to mitigation and adaptations are crucial.

Objectives of the Study. The broad objective is to evaluate socio-economic factors influencing perceptions and adaptability of rural rice farmers to climate change in Abuja, Nigeria: applications of Heckman two-stage model. The study was designed specifically to achieve the following objectives:

- describe the socio-economic profiles or characteristics of rural rice farmers;

- determine the perceptions of rural rice farmers to climate change;

- determine the adaptation or coping strategies of rural rice farmers to climate change;

- evaluate socio-economic factors influencing perceptions and adaptability of rural rice farmers to climate change;

- determine the problems or constraints facing rural rice farmers' adaptability to climate change.

\section{METHODS OF RESEARCH}

The Study Area. The study was conducted in Gwagwalada, Abuja, Nigeria. Gwagwalada is an area council located at Latitudes 80 55' 59" North of the Equator and Longitudes 70 5' 59" East of the meridian. The study area was characterized by high humidity, which has a heat trap effect. There are notably two main seasons; the wet and dry seasons. Annual rainfall, ranges from $1100 \mathrm{~mm}$ to $1700 \mathrm{~mm}$. The climatic conditions of the study area permit agricultural activities such as cultivation of crops, grazing of animals and fishery production. Gwagwalada Area Council has a total land mass of about 1,043 Square Kilometer and with a population of 157,770 people (NPC, 2006). Average annual rainfall ranges from 800 to $1,500 \mathrm{~mm}$ and temperature ranges between $21^{\circ} \mathrm{C}-35^{\circ} \mathrm{C}$.

Sampling Techniques and Sample Size. Purposive sampling technique was adopted and employed in choosing Abuja, Nigeria. This is because of predominant rural rice farmers in the area. Multi-stage was adopted and employed in choosing the rural rice farmers, they are target respondents. First stage involves the selection of Gwagwalada out of six (6) area councils using simple random sampling technique employing ballot-box raffle draw method. Second stage involves the selection five (5) wards out of ten (10) wards using simple random selection technique employing ballot-box raffle draw method. Third stage involves the selection of two (2) villages per ward using simple random sampling technique employing ballot-box raffle draw method. Fourth and final stage involves the selection of five (5) rural rice farmers, they are the target respondents, the rural rice farmers were selected using simple random sampling technique employing ballot-box raffle draw method. The total sample size was 100 rural rice farmers in the area.

Method of Data Collection. This study employed primary data. Primary data involves the use of well-designed and well-structured questionnaire. The questionnaire was designed to capture all variables necessary to achieve the broad objective and specific objectives stated. The questionnaire captured variables like the socio-economic profiles or characteristics of rural rice farmers such as age, household size, experiences in rice production, marital status, and educational status. The questionnaires was also designed to capture the perceptions of rural rice farmers to climate change, the adaptation strategies of rural rice farmers to climate change, and constraints or problem facing rural rice farmers adaptability to climate change. The questionnaire was subjected to reliability and validity tests. The questionnaire was designed taking notice of observations arising from reliability and validity tests conducted. The questionnaire was administered to rural rice farmers with the help of well-trained enumerators.

Method of Data Analysis. The following statistical and econometric tools were used to achieve the stated broad and specific objectives:

- Descriptive Statistics;

- Four-Point Likert Scale;

- Perception Use Index; 
- Problem Confrontation Index;

- Adaptation or Coping Strategy Use Index;

- Heckman Two-Stage Model;

- Probit Model;

- Tobit Model or Truncated Regression Model;

- t-Test Analysis;

- Principal Component Analysis.

Descriptive Statistics. This involves or encompasses the use of frequency distributions, mean, percentages. Descriptive statistics was used to have a summary statistics of data obtained from the field. This was used to achieve specific objectives one (i), and five (v) which identifies the socio-economic profiles or characteristics of rural rice farmers and constraints or problems facing rural rice farmers.

Four Point Likert-Scale. To ascertain the rice farmer's perceptions, coping strategies and constraints faced by rural rice farmers, a four-point Likert- scale was used. To ascertain the rice farmers perceptions of climate change, the response options and values assigned will be as follows: Frequently Encountered $=4$; Occasionally Encountered $=3$; Rarely Encountered $=2$, and Not-Encountered $=1$. To ascertain rural rice farmers adaptability strategies or coping strategies and constraints, the response options and values assigned will be as follows: Regular Practice $=4$, Occasional Practice $=3$, Rarely Practice $=2$, Not Practice $=1$. These values will be added and divided by 4 to obtain 2.5 , which will be regarded as the mean.,Perceptions, strategies or problems with mean scores (MS) greater than or equal to 2.5 will be regarded as "Significant" while perceptions, strategies or problems with mean responses lower than 2.5 will be regarded as "Non-Significant". The mean scores were calculated using the formula below:

$$
M S=\frac{\sum[R P \times O]}{\sum F}
$$

Where: MS = Mean Score (Units), RP = Rating Point (Units), $\mathrm{O}=$ Observations (Units), $\Sigma F=$ Total Number of Sampled Respondents (Units).

This was used to achieve part of specific objectives two (ii), three (iii) and five (v).

Perceptions of Use Index (PUI). Rural rice farmers were asked to rate their perceptions on climate change on a four- point Likert scale. The Perceptions of Use Index is stated thus:

$$
P U I=P_{f e} X_{0}+P_{o e} X_{1}+P_{r e} X_{2}+P_{n e} X_{3}
$$

Where: $P U I=$ Perception of Use Index (Units), $P_{f e}=$ Frequency of the Rural Rice Farmers' who Perceived Climate Change as Frequent, Encountered (Units), $P_{o e}=$ Frequency of the Rural Rice Farmers' who Perceived Climate Change as Occasionally, Encountered (Units), $P_{r e}=$ Frequency of the Rural Rice Farmers' who Perceived Climate Change as Rarely Encountered (Units), $P_{n e}=$ Frequency of the Rural Rice Farmers' who Perceived Climate Change as Not-Encountered (Units).

This was be used to achieve part of specific objective two (ii).

Adaptation Strategy Use Index (ASUI). This was used to determine the adaptation strategies use index for individual coping strategies. This was computed to find out how many rural rice farmers responded as using the climate change coping strategies. This model is adopted following Mardy, Uddin, Sarker, Roy, and Dunn, (2018).

$$
A S U I=A S_{r} \times 4+A S_{O} \times 3+A S_{r} \times 2+A S_{n} \times 1
$$

Where: $A S U I=$ Adaptation Strategy Use Index, $A S_{r}=$ Number of responses with regular practice of climate change coping strategies, $A S_{O}=$ Number of responses with occasional practice of climate change coping strategies, $A S_{r}=$ Number of responses with rare practice of 
climate change coping strategies, $A S_{n}=$ Number of responses with no practice of climate change coping strategies.

This was used to achieve part of specific objective three (iii).

Problem Confrontation Index. Rural rice farmers were asked to rate their perceptions of each constraints faced in adopting coping strategies against climate change on a four- point Likert scale. The Problem Confrontation Index is stated thus:

$$
P C I=P_{n} X_{0}+P_{l} X_{1}+P_{m} X_{2}+P_{h} X_{3}
$$

Where: $\mathrm{PCl}=$ Problem Confrontation Index (Units), $P_{n}=$ Frequency of the Rice farmers who rated the problems as Not Encountered (Units), $P_{l}=$ Frequency of the Rice farmers who rated the problems as Rarely-Encountered (Units), $P_{m}=$ Frequency of the Rice farmers who rated the problems as Occasionally Encountered (Units), $P_{h}=$ Frequency of the Rice farmers who rated the problems as Frequently Encountered (Units).

This was used to achieve specific objective six (vi).

Principal Component Analysis. Constraints faced by rural rice farmers were subjected to Principal Component Analysis or Factor Analysis. The principal Component Analysis is stated thus:

$$
\begin{aligned}
& x=\left(x_{1}, x_{2}, x_{3}, \ldots, x_{p} \ldots \ldots \ldots\right. \\
& \alpha_{K}=\left(\alpha_{1 k}, \alpha_{2 k}, \alpha_{3 k}, \ldots \alpha_{p k}\right) \\
& \alpha_{k}^{T} X=\sum_{j=1}^{p} \alpha_{k j} X_{j} \ldots \ldots \ldots \ldots \ldots \\
& \text { Var }=\left[\alpha_{k}^{T} X\right] \text { is Maximum }
\end{aligned}
$$

Subject to:

$$
\begin{gathered}
\alpha_{k} \alpha_{K}=1 \ldots \ldots \ldots \ldots \\
\operatorname{cov}\left[\alpha_{1}^{T} X-\alpha_{2}^{T} X\right]=0
\end{gathered}
$$

The variances of each of the principal components are:

$$
\begin{gathered}
\operatorname{Var}\left[\alpha_{k}^{T} X\right]=\lambda_{k} \\
S=\frac{1}{n-1}(X-X)(X-\bar{X})^{\top} \\
S=\frac{1}{n-1} \sum_{i=1}^{n}\left(X_{i}-\bar{X}_{i}\left(X_{i}-\bar{X}_{i}\right)^{\top}\right.
\end{gathered}
$$

Where: $\mathrm{X}=$ Vector of $\mathrm{p}$ Random Variables, $\alpha_{k}=$ Vector $\mathrm{p}$ Components, $\lambda_{K}=$ Eigen Value, $\mathrm{T}=$ Transpose, $\mathrm{S}=$ Covariance Matrix.

This was used to achieve specific objective five (v).

Heckman Two-Stage Model. The Probit Model is stated thus:

$$
\begin{gathered}
\mathrm{Z}_{\mathrm{i}}=\mathrm{f}\left(\mathrm{X}_{1}, \mathrm{X}_{2}, \mathrm{X}_{3}, \mathrm{X}_{4}, \mathrm{X}_{5}, \mathrm{X}_{6}, \mathrm{X}_{7}, \mathrm{X}_{8}, \mathrm{X}_{9}, \mathrm{X}_{10}, \mathrm{X}_{11}, \mathrm{X}_{12}, \mathrm{U}_{\mathrm{i}}\right) \\
Y_{i}=b_{0}+\sum_{i=1}^{12} b_{i} X_{i}+U_{i}
\end{gathered}
$$

The explicit function is stated thus:

$$
\begin{gathered}
\mathrm{Y}_{\mathrm{i}}=\mathrm{b}_{0}+\mathrm{b}_{1} \mathrm{X}_{1 .} \ldots \ldots+\mathrm{b}_{10} \mathrm{X}_{10}+\mathrm{U}_{\mathrm{i}} \\
Z_{i}=\beta_{0}+\beta_{1} X_{1}+\beta_{2} X_{2}+\beta_{3} X_{3}+\beta_{4} X_{4}+\beta_{5} X_{5}+\beta_{6} X_{6}+\beta_{7} X_{7}+\beta_{8} X_{8}+\beta_{9} X_{9}+\beta_{10} X_{10}+\beta_{11} X_{11}+\beta_{12} X_{12}+U_{i}
\end{gathered}
$$

Where: $Z_{i}=$ Dichotomous Climate Change Response Variable (1, Perceived Climate Change; 0 , Otherwise), $X_{1}=$ Age of Rural Rice Farmers (Years), $X_{2}=$ Gender Dummy (1, Male; 0 , Female), $X_{3}=$ Marital Status (1, Married; 0, Otherwise), $X_{4}=$ Household Size (Units), $X_{5}=$ 
Educational Level (0, Non-Formal; 1, Primary; 2, Secondary; 3 , Tertiary), $\mathrm{X}_{6}=$ Access to Credit Facilities (Naira), $\mathrm{X}_{7}=$ Access to Information of Climate Change (1, Access; 0 , Otherwise), $\mathrm{X}_{8}=$ Farm Experience (Years), $\mathrm{X}_{9}=$ Farm Size (Hectares), $\mathrm{X}_{10}=$ Access to Adaptive Measures (1, Access; 0, Otherwise), $\mathrm{X}_{11}=$ Extension Services Dummy (Number of Extension Contact in a Month), $X_{12}=$ Access to Market (1, Access; 0 , Otherwise), $\beta_{1}-\beta_{12}=$ Regression Coefficients, $\beta_{0}=$ Constant Term, $\mathrm{U}_{\mathrm{i}}=$ Error Term.

This was used to achieve specific objective four (iv).

Ordinary Least Squares Regression Model (OLS). The Ordinary Least Square Regression model is stated thus:

$$
Y=b_{0}+\sum_{i=1}^{13} b_{i} X_{i}+\varepsilon_{i}
$$

The explicit function is stated:

$$
\begin{aligned}
& Y_{i}=\beta_{0}+\beta_{1} X_{1}+\beta_{2} X_{2}+\beta_{3} X_{3}+\beta_{4} X_{4}+\beta_{5} X_{5}+\beta_{6} X_{6}+\beta_{7} X_{7}+\beta_{8} X_{8} \\
+ & \beta_{9} X_{9}+\beta_{10} X_{10}+\beta_{11} X_{11}+\beta_{12} X_{12}+\beta_{13} X_{13}+\varepsilon_{i}
\end{aligned}
$$

Where:

$Y_{i}=$ Climate Change Adaptive Measures Used by Rural Rice Farmers (Units);

$\mathrm{X}_{1}=$ Age of Rural Rice Farmers (Years);

$\mathrm{X}_{2}=$ Gender Dummy (1, Male; 0, Female);

$\mathrm{X}_{3}=$ Marital Status (1, Married; 0, Otherwise);

$\mathrm{X}_{4}=$ Household Size (Units);

$\mathrm{X}_{5}=$ Educational Level (0, Non-Formal; 1, Primary; 2, Secondary; 3, Tertiary);

$\mathrm{X}_{6}=$ Access to Credit Facilities (Naira);

$\mathrm{X}_{7}=$ Access to Information of Climate Change (1, Access; 0, Otherwise);

$\mathrm{X}_{8}=$ Farm Experience (Years);

$\mathrm{X}_{9}=$ Farm Size (Hectares);

$\mathrm{X}_{10}=$ Access to Adaptive Measures (1, Access; 0, Otherwise);

$\mathrm{X}_{11}=$ Extension Services Dummy (Number of Extension Contact in a Month);

$\mathrm{X}_{12}=$ Access to Market (1, Access; 0, Otherwise);

$\mathrm{X}_{13}=$ Inverse Mill Ratio (Units);

$\beta_{1}-\beta_{13}=$ Regression Coefficients;

$\beta_{0}=$ Constant Term;

$\varepsilon_{i}=$ Error Term.

This was used to achieve specific objective four (iv).

\section{RESULTS AND DISCUSSION}

Socio-Economic Profiles or Characteristics of Rural Rice Farmers. Table 1 shows the socio-economic profiles or characteristics of rural rice farmers. In terms of age, $73 \%$ of rural rice farmers were less than 50 years. This means that rural rice farmers were young, active, and energetic.

The activities involved in producing rice require labour, and needs a lot of energy. The youthful age of the farmers will enable them to deploy enough labour and energy resources towards rice production. The young farmers will also be able to adopt new innovations and technologies brought to them easily by extension officers. About $96 \%$ of rural rice farmers had formal education, and were literate. Educated farmers will be able to read and understand research findings and adopt new innovations easily. Rural rice farmers on the average had 7 people in the households. The average years of experience for rural rice farmers were 8 years. Furthermore, $43 \%$ of rural rice farmers had less than 2 hectares of rice farms. This result agrees or is in line with findings of Alabi and Ibraheem (2018) and Alabi, Ayoola, and Saidu (2010), Alabi and Ajooku (2012). 
Table 1 - Socio-Economic Profiles or Characteristics of Rural Rice Farmers

\begin{tabular}{|l|l|l|l|}
\hline \multicolumn{1}{|c|}{ Socio-Economic Profiles } & Frequency & Percentage & Mean \\
\hline Age (Years) & 17 & 17.00 & 46.5 \\
$31-40$ & 56 & 56.00 & \\
$41-50$ & 27 & 27.00 & \\
$51-60$ & 67 & 67.00 & \\
Sex & 33 & 33.00 & \\
Male & & & \\
Female & 27 & 27.00 & \\
Marital Status & 76 & 76.00 & \\
Single & 07 & 07.00 & \\
Married & & & \\
Widow & 26 & 26.00 & \\
Educational Status & 43 & 43.00 & \\
Primary & 27 & 27.00 & \\
Secondary & 04 & 04.00 & \\
Tertiary & 34 & & \\
Non-Formal & 34.28 & \\
Household Size(Units) & 43 & 43.00 & \\
$1-5$ & 13 & 13.00 & \\
$6-10$ & 10 & 10.00 & \\
$11-15$ & & & \\
$16-20$ & 23 & 23.00 & \\
Experience in & 43 & 43.00 & \\
Farming (Years) & 32.00 & \\
$1-5$ & 32 & 02.00 & \\
$6-10$ & 02 & 43.00 & \\
$11-15$ & 43 & 36.00 & \\
$16-20$ & 36 & 21.00 & \\
Farm Size (Ha) & 21 & 100.00 & \\
$1.0-2.0$ & 100.00 & & \\
$2.01-3.0$ & & & \\
$3.01-4.0$ & & & \\
Total & & & \\
\hline
\end{tabular}

Source: Field Survey (2019), Computed from STATA Version 14.

Rural Rice Farmers Perceptions about Climate Change. As shown in Table 2, rural rice farmers perceived, observed, and had experience the events of climate change. Rural rice farmers perceived that climate change reduces the yields of rice production. This event was ranked first in terms of perceived use index.

Table 2 - Rural Rice Farmers Perceived Climate Changes

\begin{tabular}{|l|l|l|l|l|l|c|}
\hline \multicolumn{1}{|c|}{ Perceived Climate Changes } & $\begin{array}{l}\text { FE } \\
(4)\end{array}$ & $\begin{array}{c}\text { OE } \\
(3)\end{array}$ & $\begin{array}{l}\text { RE } \\
(2)\end{array}$ & $\begin{array}{l}\text { NE } \\
(1)\end{array}$ & PUI & Rank \\
\hline Higher Temperatures & 35 & 47 & 51 & 21 & 404 & $7^{\text {th }}$ \\
Drought Occurrence & 31 & 49 & 50 & 29 & 400 & $8^{\text {th }}$ \\
Flood Occurrence & 36 & 50 & 60 & 21 & 435 & $4^{\text {th }}$ \\
Reduced Rainfall & 37 & 47 & 44 & 41 & 418 & $6^{\text {th }}$ \\
Increased Rainfall & 51 & 38 & 61 & 39 & 540 & $3^{\text {rd }}$ \\
Changes in Time of & & & & & & \\
Planting & 60 & 71 & 75 & 59 & 662 & $2^{\text {nd }}$ \\
Reduce Yields & 75 & 70 & 60 & 61 & 691 & $1^{\text {st }}$ \\
Warming & 60 & 41 & 21 & 18 & 423 & $5^{\text {th }}$ \\
Desertification's & 19 & 11 & 21 & 20 & 171 & $9^{\text {th }}$ \\
Salinity & 17 & 12 & 11 & 11 & 137 & $10^{\text {th }}$ \\
\hline
\end{tabular}

$F E=$ Frequently Encountered, $O E=$ Occasionally Encountered, $R E=$ Rarely Encountered, NE=Not Encountered. Source: Field Survey (2019), Computed Using STATA Version 14.

Changes in time of planting, and increased rainfall were ranked $2^{\text {nd }}$ and $3^{\text {rd }}$ respectively based on the perceptions of rice farmers towards events of climate change. Flood 
occurrences, warming and reduced rainfall were ranked $4^{\text {th }}, 5^{\text {th }}$ and $6^{\text {th }}$ respectively due to perceptions of rural rice farmers to events of climate change. This result agrees or is in line with findings of Apata (2011), Belay, Rechay, Woldeamanuel, and Morton (2017).

Adaptive Measures Used by Rural Rice Farmers. The adaptive measures used by rural rice farmers were shown in Table 3.Rural rice farmers respond by using different adaptation strategies to reduce the variability in climate. The adaptive measures were used by rural rice farmers to reduce the impact of climate change.

Table 3 - Adaptive Strategies Used by Rural Rice Farmers

\begin{tabular}{|l|c|c|c|c|c|c|}
\hline \multicolumn{1}{|c|}{ Adaptive Measures } & $\begin{array}{c}\text { RP } \\
(4)\end{array}$ & $\begin{array}{c}\text { OP } \\
(3)\end{array}$ & $\begin{array}{c}\text { RaP } \\
(2)\end{array}$ & $\begin{array}{c}\text { NP } \\
(1)\end{array}$ & PUI & Rank \\
\hline Planting Heat and Drought & 21 & 36 & 51 & 49 & 343 & $12^{\text {th }}$ \\
Resistance Varieties & 36 & 51 & 57 & 31 & 442 & $10^{\text {th }}$ \\
Adopting Soil and Water & & & & & & \\
Conservation Method & 37 & 47 & 46 & 39 & 420 & $11^{\text {th }}$ \\
Zero Tillage & 51 & 57 & 61 & 60 & 557 & $7^{\text {th }}$ \\
Use of Fertilizers & 57 & 59 & 60 & 59 & 584 & $6^{\text {th }}$ \\
Salinity Tolerant Varieties & 51 & 49 & 60 & 51 & 522 & $8^{\text {th }}$ \\
Use Irrigation Facilities & 61 & 59 & 71 & 58 & 621 & $3^{\text {rd }}$ \\
Crop Diversification & 71 & 60 & 39 & 51 & 593 & $5^{\text {th }}$ \\
Integrating Crop with Livestock & 60 & 61 & 67 & 59 & 616 & $4^{\text {th }}$ \\
Use Improved Varieties & 71 & 61 & 51 & 57 & 626 & $2^{\text {nd }}$ \\
Changing Time/Date of Planting & 81 & 61 & 67 & 61 & 702 & $1^{\text {st }}$ \\
Practicing Intercropping & 49 & 41 & 49 & 47 & 464 & $9^{\text {th }}$ \\
Crop Insurance & & & &
\end{tabular}

$R P=$ Regular Practiced, $O P=O c c a s i o n a l l y$ Practiced, $R a P=$ Rare Practiced, $N P=$ Not Practiced.

Source: Field Survey (2019), Computed Using STATA Version 14.

Intercropping, changing the date and time of planting and crop diversifications were ranked $1^{\text {st }}, 2^{\text {nd }}$, and $3^{\text {rd }}$ respectively as the most practiced or preferred adaptive measures used to reduce the impact of climate change by rural rice farmers. Other adaptive measures or strategies used by rural rice farmers include: the use of improved rice varieties, integrating crop with livestock production, use of salinity tolerant varieties, and these were ranked $4^{\text {th }}$, $5^{\text {th }}$, and $6^{\text {th }}$ respectively. This results agrees or is in line with findings of Uddin, Bokelmann and Entsminger (2014), Mengistu and Haji (2015).

Estimates of Heckman Two-Stage Model. The parameter estimates of Heckman two stage model was presented in Table 4. The first stage presented the perception model of rural rice farmers to events of climate change. The second stage presented the adaptability model which presented measures used by rural rice farmers to reduce the impact of climate change. The Wald square value of 78.61 and Log-Likelihood value of -109.321 were significant at $(P<0.01)$, this shows that explanatory or exogenous or predictor variables included in the model were strong enough and were jointly responsible in explaining the perceptions of rural rice farmers to events of climate change and also jointly responsible in explaining adaptive measures of rural rice farmers in reducing the impact of climate change as stated in the Heckman two-stage model.

Thirteen (13) exogenous variables were included in the Heckman two - stage model. The exogenous variables were: age, gender, marital status, household size, educational status, access to credit facilities, access to information on climate, farm experience, farm size, access to adaptive measures, extension services, access to market, and inverse mill ratio. Six (6) exogenous variables were statistically significant in influencing perceptions of rural rice farmers to events of climate change. The six (6) predictor variables and their levels of significant were: age $(P<0.05)$, educational status $(P<0.01)$, access to information on climate $(P<0.01)$, farm experience $(P<0.01)$, farm size $(P<0.05)$, and extension services $(P<0.01)$. As rural rice farmers get educated and become literate there is probability or likelihood that rice farmers' perceptions to events of climate change would increase marginally by 0.3118 units. Furthermore, as rural rice farmers' have access to information on climate change, there is probability or likelihood that perceptions of events of 
climate change by rural rice farmers would increase marginally by 0.2714 units. Eleven (11) exogenous or regressor variables were statistically significant in influencing the adaptability of rural rice farmers to impact of climate change by rural rice farmers'. The eleven (11) variables that were statistically significant and their levels of probabilities were: age $(P<$ 0.05), gender $(P<0.05)$, household size $(P<0.05)$, educational status $(P<0.01)$, access to credit $(P<0.01)$, farm experience $(P<0.05)$, farm size $(P<0.05)$, access to adaptive measures $(P<0.01)$, extension services $(P<0.01)$, access to market $(P<0.01)$, and inverse mill ratio $(P<0.05)$. All the coefficients had positive impacts on rural rice farmers employing adaptive measures to reduce the impacts of climate change. In terms of gender, male-headed households will have higher probability or likelihood of planting trees, integrating crops with livestock, soil and water conservation and other climate change adaptive measures. Farm size had positive coefficient, an increase in farm size increases the likelihood or probability of rural rice farmers planting different types of fodder crops, adopting soil and water conservation, use of improved varieties and other climate change adaptive measures. Access to market both ]in terms of inputs and output will enable rural rice farmers have access and buy fertilizer inputs, pesticides, improved varieties of crops and output sales of produce. Extension services will enable or increase the likelihood or probability of rural rice farmers have access to research findings, improved varieties of crops, tree planting, crop diversifications and other climate change adaptive measures. The coefficient of multiple determinations, R-square value was 0.7634 .This means the exogenous variables included in the Heckman two-stage model explained $76.34 \%$ measures of adaptive strategies used by rural rice farmers to reduce the impact of climate change. The F-value of 363.92 was significant at $(P<0.01)$. This means that the variables included in the model were jointly responsible in explaining the variations in adaptive measures used by rural rice farmers in reducing the impact of climate change. This result agrees or is in line with findings of Apata (2011), Belay, Rechay, Woldeamanuel, and Morton (2017), Uddin, Bokelmann and Entsminger (2014), Mengistu and Haji (2015).

Table 4 - Results of Heckman Two-Stage Model

\begin{tabular}{|c|c|c|c|c|}
\hline \multirow{2}{*}{ Variables } & \multicolumn{2}{|c|}{ Probit Perception Model } & \multicolumn{2}{|c|}{ OLS Adaptive Model } \\
\hline & Coefficient & Marginal Effects & Coefficients & t-Value \\
\hline Age $\left(X_{1}\right)$ & $0.1431^{* *}$ & 0.1671 & $0.3151^{* \star}$ & 2.512 \\
\hline Gender $\left(X_{2}\right)$ & 0.1161 & 0.2161 & $0.1131^{\star *}$ & 2.54 \\
\hline Marital Status ( $\mathrm{X}_{3}$ ) & 0.2131 & 0.1167 & 0.1421 & 1.03 \\
\hline Household Size $\left(X_{4}\right)$ & 0.2215 & 0.1516 & $0.4214^{\star \star}$ & 2.91 \\
\hline Educational Status $\left(\mathrm{X}_{5}\right)$ & $0.4751^{* * *}$ & 0.3118 & $0.3711^{\star \star \star}$ & 3.12 \\
\hline Access to Credit $\left(\mathrm{X}_{6}\right)$ & 0.3141 & 0.1169 & $0.4213^{\star \star \star}$ & 3.22 \\
\hline Access to Information of Climate & $0.3761^{\star \star \star}$ & 0.2714 & --------- & ----- \\
\hline Change $\left(X_{7}\right)$ & & & & \\
\hline Farm Experience $\left(\mathrm{X}_{8}\right)$ & $0.3541^{* \star \star}$ & 0.2514 & $0.4133^{* \star}$ & 2.81 \\
\hline Farm Size $\left(X_{9}\right)$ & $0.3242^{\star *}$ & 0.3171 & $0.1402^{\star \star}$ & 2.93 \\
\hline Access to Adaptive Measures $\left(\mathrm{X}_{10}\right)$ & --------- & ------ & $0.1681^{\star \star \star}$ & 3.31 \\
\hline Extension Services $\left(\mathrm{X}_{11}\right)$ & $0.3314^{\star \star}$ & 0.2161 & $0.3192^{\star \star \star}$ & 3.01 \\
\hline Access to Market $\left(\mathrm{X}_{12}\right)$ & --------- & ------ & $0.5192^{\star \star \star}$ & 2.98 \\
\hline Inverse Mill Ratio ( $\mathrm{X}_{13}$ ) & -------- & ------ & $0.1692^{\star *}$ & 2.81 \\
\hline Number of Observations & 100 & ------- & -------- & \\
\hline Wald Chi Square & $78.61^{\star * *}$ & ------- & ------- & \\
\hline Log-Likelihood & -109.321 & ------- & ------ & \\
\hline Pseudo $R^{2}$ & 0.6131 & ------- & ------- & \\
\hline $\mathrm{R}^{2}$ Value & ------- & ------- & 0.7934 & \\
\hline Adjusted $\mathrm{R}^{2}$ & --------- & ------- & 0.7621 & \\
\hline F-Value & ---------- & -------- & $363.92^{\star \star \star}$ & \\
\hline
\end{tabular}

Source: Field Survey (2019), Computed Using STATA Version 14.

Problems Facing Rural Rice Farmers Ranked Using Problem Confrontation Index. Rural rice farmers were asked to rate problems facing them in perceiving the events of climate change, and also in using the adaptive measures to reduce the impact of climate change. The problems were examined using four-point Likert scale which ranges from 
frequently-encountered (4 points) to not-encountered (1 point). The results was presented in Table 5. Bad road infrastructures, lack of information on climate change, lack of access to input and output markets.

Table 5 - Problems Confrontation Index (PCI) of Rural Rice Farmers

\begin{tabular}{|l|c|c|c|c|c|c|}
\hline \multicolumn{1}{|c|}{ Problems } & FE & OE & RE & NE & PCI & Rank \\
\hline Inadequate Extension Officer & 41 & 31 & 62 & 14 & 395 & $9^{\text {th }}$ \\
Lack of Credit Facilities & 51 & 49 & 71 & 53 & 546 & $6^{\text {th }}$ \\
Lack of Information on Climate & 61 & 81 & 79 & 78 & 723 & $2^{\text {nd }}$ \\
Change & 71 & 79 & 63 & 77 & 724 & $1^{\text {st }}$ \\
Bad Road Infrastructure & 67 & 71 & 77 & 76 & 711 & $3^{\text {rd }}$ \\
Lack Access to Market & 71 & 61 & 69 & 72 & 677 & $4^{\text {th }}$ \\
Lack of Irrigation Facilities & 70 & 56 & 55 & 59 & 617 & $5^{\text {th }}$ \\
Lack of Access to Land Input & 31 & 41 & 56 & 55 & 414 & $8^{\text {th }}$ \\
Lack of Labour Input & 29 & 67 & 61 & 53 & 492 & $7^{\text {th }}$ \\
\hline Inadequate Farm Inputs &
\end{tabular}

$F E=$ Frequently Encountered, $O E=$ Occasionally Encountered, $R E=$ Rarely Encountered, NE=Not Encountered. Source: Field Survey (2019), Computed Using STATA Version 14.

Lack of irrigation facilities were ranked $1^{\text {st }}, 2^{\text {nd }}, 3^{\text {rd }}$ and $4^{\text {th }}$ respectively based on problem confrontation index. This results agrees or is in line with findings of Uddin, Bokelmann and Entsminger (2014), Mengistu and Haji (2015).

Principal Component Analysis Results of Constraints or Problems Facing Rural Rice Farmers in Perceiving and Adapting to Climate Change. Table 6 presents the results of principal component analysis for constraints facing rural rice farmers in perceiving events of climate change or adapting measures in reducing the impacts of climate change. Principal component analysis is statistical and econometric tools that reduce many interrelated data into few uncorrelated data or variables. The principal components retained five (5) variables based on Kaiser Meyer Criterion the fact that they have Eigen values greater than one. The retained variables or components explained $88.89 \%$ of total variations of all components included in the model. The Kaiser-Meyer Olkin measures of sampling adequacy (KMO) of 0.6913 and Bartlett test of sphericity of 2061.007 was significant at $(P<0.01)$. Lack of information on climate change, bad road infrastructures, and lack of irrigation facilities were ranked $1^{\text {st }}, 2^{\text {nd }}$, and $3^{\text {rd }}$, respectively based on the perceptions and adaptability of rural rice farmers to climate change.

Table 6 - Principal Component Analysis of Constraints or Problems Facing Rural Rice Farmers

\begin{tabular}{|l|l|l|l|l|}
\hline \multicolumn{1}{|c|}{ Constraints } & \multicolumn{1}{|c|}{ Eigen-Value } & Difference & Proportion & Cumulative \\
\hline Lack of Information & 3.1492 & 0.1892 & 0.2156 & 0.2156 \\
about Climate & & & & \\
Bad Road Infrastructures & 2.1261 & 0.1723 & 0.1751 & 0.3907 \\
Lack of Irrigation & 1.831 & 0.1651 & 0.2141 & 0.6048 \\
Facilities & & & \\
Lack of Access to Market & 1.621 & 0.1531 & 0.1821 & 0.7869 \\
Lack of Credit Facilities & 1.5123 & 0.1132 & 0.1020 & 0.8889 \\
\hline \multicolumn{2}{|l|}{ Bartlett Test of Sphericity. KMO 0.6913. Chi Square 2061.007***. Rho 1.00000. } \\
\hline
\end{tabular}

Source: Field Survey (2019), Computed Using STATA Version 14.

Lack of access to input and output markets, and lack of credit facilities with Eigen values 1.621 and 1.5123 were ranked $4^{\text {th }}$ and $5^{\text {th }}$ respectively based on the perceptions and adaptability measures of rural rice farmers to climate change.

\section{CONCLUSION}

The rural rice farmers were young, active and energetic with an average age of 46.5 years. Majority of the rural rice farmers had formal education. Averagely, about 7 people 
were in the rural rice farmers households'. The average rural rice farms were 2.28 hectares. This means they are peasant or smallholder or small-scale or marginal rural rice farmers. The mean experiences in rice farming by rural farmers were 8 years. Perception use index which observed the perceptions of rural rice farmers to events of climate changes shows that reduce yields, changes in time and date of planting, increased rainfall, and flood occurrences were ranked $1^{\text {st }}, 2^{\text {nd }}, 3^{\text {rd }}$ and $4^{\text {th }}$ respectively. Adaptive index used to examine the rural rice farmers measures to reduce the impacts of climate change revealed that intercropping, changing of time and date of planting, crop diversification, use of improved varieties, integrating crop with livestock were ranked $1^{\text {st }}, 2^{\text {nd }}, 3^{\text {rd }}, 4^{\text {th }}$ and $5^{\text {th }}$ respectively. The statistically and significant factors influencing perceptions of rural rice farmers to events of climate change include: age, educational status, access to information on climate change, farm experience, farm size, and extension services. The statistical and significant factors influencing adaptability measures to reduce the impact of climate change include: age, gender, household size, educational status, access to credit, farm experience, farm size, access to adaptive measures, extension services, and access to input,output markets, Problem confrontation index shows that bad road infrastructures, lack of information on climate change, lack of access to input and output markets and lack of irrigation facilities were ranked $1^{\text {st }}, 2^{\text {nd }}, 3^{\text {rd }}$, and $4^{\text {th }}$ respectively. Principal component analysis retained five components in analyzing constraints facing rural rice farmers. The retained components had Eigen values greater than one. They are lack of information on climate change $\left(1^{\text {st }}\right)$, bad road infrastructures $\left(2^{\text {nd }}\right)$, lack of irrigation facilities $\left(3^{\text {rd }}\right)$, lack of access to input, output market $\left(4^{\text {th }}\right)$ and lack of credit facilities $\left(5^{\text {th }}\right)$. The retained components explained $88.99 \%$ of all variables included in the model.

\section{RECOMMENDATIONS}

The following under-listed recommendations were made based on the findings of this study:

Policy measures should be in place to educate rural rice farmers on perceptions of events of climate change and adaptive measures to reduce impacts of climate change through radio, televisions, schools, social media, print media, and farmers to farmers contact;

Extension officers should be employed to disseminate information on research findings, new improved varieties, new innovations on climate change to rural rice farmers;

Access to input and output markets should be provided for rural rice farmers to access fertilizers, pesticides, farm inputs and also offer marketable rice produce for sales;

Adaptive measures such as irrigation facilities, drought resistant varieties, soil and water conservation techniques and other adaptive techniques should be made available to rural rice farmers.

\section{REFERENCES}

1. Abah, D.A, Abu, G.A, and Ater, P.I (2015). Analysis of the Performance of Paddy Rice Marketing in Benue State, Nigeria. Journal of Agricultural Science and Engineering 1(3) 143-152.

2. Agbogo, E.A, Uduoso, A.B, and Tiku, E.N (2013). Analysis of Factors Affecting Rice Consumption in Cross River State, Nigeria. Journal of Agriculture and Veterinary Sciences 4 (2): $34-40$.

3. Alabi,O.O., Ibraheem, A. (2018). Economics of Maize (Zea mays) Production in Igabi Local Government of Kaduna State, Nigeria. Journal of Agricultural Faculty of Gaziosmanpasa University (JAFAG) .Volume 35 (3): 248-257.

4. Alabi, O. O., Ayoola, A.O., Saidu, H. (2010). Resource-Use Efficiency and Economies of Scale of Maize-Rice Intercropping Mixture in Bosso Local Government Area of Niger State, Nigeria,International Journal of Agriculture and Rural Development (IJARD) 1(2):147-152. 
5. Alabi O.O., Ajooku, H.A. (2012).Socio-Economic Factors Influencing Cassava Production in Kuje and Abaji Area Councils of Federal Capital Territory, Abuja, Nigeria, Journal of Agriculture, Forestry and Social Sciences (JOAFSS),10(2):73-84.

6. Apata, T.G (2011). Factors Influencing the Perception and Choice of Adaptation Measures to Climate Change among Farmers in Nigeria: Evidence from Farm Households in Southwest Nigeria. Environmental Economics 2 (4): 74-83.

7. Belay, A, Recha, J.W, Woldeamanuel, T and Morton, J.F (2017). Smallholder Farmers' Adaptation to Climate Change and Determinants of their Adaptation Decisions in the Central Rift Valley of Ethiopia. Agriculture and Food Security 6 (24) 1-13

8. Edoka, .M.H, Adejoh, S.O, and Ibrahim, .M.K (2009). The Role of Women in Rice Production in Idah Local Government Area of Kogi State, Nigeria. Proceedings of the $43^{\text {rd }}$ Annual Conference on Agricultural Society of Nigeria, October 19-23 Abuja

9. Ekeleme, F, Karama, A.Y, Omoigui, L.O, Tegbaru, A, Mshelia, J and Onyibe, J.E (2008). Guide to Rice Production in Borno State, Nigeria.IITA, Ibadan, Nigeria, 20pp.

10. Evans, C, Storer, C and Wardell-Johnson, A (2011). Rural Farming Community Climate Change Acceptance: Impact of Science and Government Credibility. International Journal of Society of Agriculture and Food 8 (3): 217 -235.

11. Marambe, B,Weerahewa, J, Pushpakumara, G, Silva, P, Punyawardena, P,Premalal, S, Miah, G, Roy, J and Jana, S (2012b). Adaptation to Climate Change in Agro-Ecosystems: A Case Study from Homegardens in South Asia. Proceedings of the MARCO Symposium 2012-Strenghtening Collaborations to Meet Agro-Environmental Challenges in Monsoon Asia 24-27 Sept, Tsukuba Japan: The Monsson Asia Agro-Environmental Consortium.

12. Mardy, T., Uddin, M.N., Sarker M.A., Roy, D., and Dunn, E.S (2018). Assessing Coping Strategies in Response to Drought: A Micro Level Study in the North-West Region of Bangladesh. Climate 6(2):23.

13. Mengisti, D and Haji, J (2015). Factors Affecting the Choices of Coping Strategies for Climate Extremes: The Case of Yabello Districts, Borana Zone, Oromia National Regional State, Ethiopia. Science Research 3 (4): 129 - 136.

14. MERET (2009). Managing Environmental Resource to enable more Transition to Sustainable

15. Livelihood. MERET News Copenhagen Climate Change Summit Special Edition, Addis Ababa.

16. Uddin, M.S, Bokelmann, W, and Entsminger, J.S (2014).Factors Affecting Farmers Adaptation Strategies to Environmental Degradation and Climate Change Effects: A Farm Level Study in Bangladesh. Climate 2 223-241. 